\title{
KARAKTERISTIK PENDERITA Ca MAMMAE TAHUN 2008 - 2009 DI RUANG CENDERAWASIH I RSUD ARIFIN ACHMAD PEKANBARU
}

\author{
Wiwik Norlita, Tri Siwi KN dan Arnita
}

\begin{abstract}
Staf Pengajar Program Studi D III Keperawatan Fakultas MIPA dan Kesehatan Universitas Muhammadiyah Riau Alumni Program Studi D III Keperawatan - F MIPA dan Kesehatan UMRI

Email: wnorlita@yahoo.com, Naningningrum @ yahoo.co.id
\end{abstract}

\begin{abstract}
ABSTRAK
Penderita Carsinoma (Ca) Mamae di seluruh dunia, terus mengalami peningkatan, baik pada daerah dengan insiden tinggi di negara-negara barat maupun pada insiden rendah seperti di Asia. Dewasa ini jumlah penderita Carsinoma (Ca) Mamae diprediksikan terus meningkat. Bila tidak ada perbaikan yang signifikan dari faktor gaya hidup dan kemajuan tehnik pengobatan. Para ahli memperkirakan pada tahun 2024 nanti satu dari tujuh wanita akan terkena Carsinoma (Ca) Mamae. Tujuan penelitian ini adalah untuk melihat gambaran karakteristik penderita Carsinoma (Ca) Mamae tahun 2008-2009 di RSUD Arifin Achmad Pekanbaru. Penelitian ini dilakukan pada tanggal 14-28 Juli 2010 di RSUD Arifin Achmad Pekanbaru.Jenis penelitian yang digunakan adalah metode deskriptifretrospektif dengan teknik pengambilan sampel purposive sampling berdasarkan ciri atau sifat-sifatpopulasi yang sudah diketahui sebelumnya dengan jumlah 411 sampel. Teknik pengumpulan data menggunakan lembaran check list dan analisa data yang digunakan adalah univariate.Hasil penelitian menunjukkan bahwa karakteristik penderita carsinoma (Ca) Mamae berdasarkan usia tahun 2008-2009 adalah mayoritas berusia 45-64 tahun sebanyak 215 orang (52,32\%). Berdasarkan jenis kelamin tahun 2008-2009 perempuan menduduki peringkat teratas setiap tahunnya sebanyak 406 orang $(98,79)$. Berdasarkan pekerjaan tahun 2008-2009 mayoritas penderita carsinoma (Ca) Mamae adalah IRT sebanyak 376 orang $(91,48 \%)$. Sedangkan Berdasarkan tingkat pendidikan tahun 2008-2009 rata-rata berpendidikan rendah (SD, SMP) sebanyak 358 orang $(87,11 \%)$.
\end{abstract}

Kata Kunci: Karakteristik, Carsinoma (Ca) Mamae, umur, jenis kelamin

\section{PENDAHULUAN}

Payudara merupakan salah satu bagian tubuh yang menjadi kebanggaan perempuan. Namun dibalik keindahan itu, tuhan menyelipkan cobaan. Ironisnya, cobaan itu juga dapat mengakibatkan kematian sehingga sering kali menjadi momok menakutkan bagi wanita. Cobaan itu adalah Carsinoma (Ca) Mamae. Dewasa ini jumlah penderita Carsinoma (Ca) Mamae diprediksikan terus meningkat. Bila tidak ada perbaikan yang signifikan dari faktor gaya hidup dan kemajuan tehnik pengobatan. Para ahli memperkirakan pada tahun 2024 nanti satu dari tujuh wanita akan terkena Carsinoma (Ca) Mamae (Chrisna, 2008).

Carsinoma (Ca) Mamae merupakan kanker yang berasal dari kelenjar, saluran dan jaringan penunjang payudara tetapi tidak termasuk kulit payudara (Mangan, 2004). Selain merupakan penyakit yang didominasi oleh wanita (99 persen), kanker ini juga merupakan penyakit yang berhubungan dengan penuaan. Resikonya meningkat tajam pada usia 30-50 tahun (Price, 2006). Hal ini disebabkan karena terjadinya ketidakseimbangan antara estrogen dan progesteron. Walaupun setelah umur 30 tahun produksi estrogen ovarium berkurang karena ovarium yang semakin mengecil, tetapi jaringan Perifer seperti lemak hati dan ginjal masih dapat menghasilkan estrogen. Sedangkan produksi progesteron semakin berkurang seiring semakin tuanya umur ovarium (Heffner \& Schust, 2006).

Pada umumnya kasus penderita Carsinoma (Ca) Mamae terdapat pada perempuan, hanya sebagian kecil saja yang terdapat pada laki-laki. Faktor resiko Carsinoma (Ca) Mamae adalah menstruasi pertama yang terlalu cepat, menopouse dini, kehamilan pertama yang terjadi di atas usia 30 tahun, serta sering terpajan radiasi di daerah dada juga dapat meningkatkan terjadinya insiden Carsinoma (Ca) Mamae (Hawari, 2004). 
Menurut WHO (2000), 8-9 persen wanita akan mengalami Carsinoma (Ca) Mamae. Hal ini menjadikan Carsinoma (Ca) Mamae sebagai jenis kanker yang paling banyak ditemui pada wanita (Liliz, 2004). Berdasarkan Globocan International Agency for Research on Cancer (IARC) tahun 2002, Carsinoma (Ca) Mamae menempati urutan pertama dari seluruh kanker pada perempuan dengan penemuan kasus baru 22,7 persen dari jumlah kematian 14 persen per tahun dari seluruh penyakit kanker yang diderita perempuan di dunia (Evy, 2008).

Jumlah penderita Carsinoma (Ca) Mamae di seluruh dunia, terus mengalami peningkatan, baik pada daerah dengan insiden tinggi di negaranegara barat maupun pada insiden rendah seperti di Asia. Satu laporan penelitian pada tahun 2003 memperkirakan bahwa jumlah kasus baru di seluruh dunia pada tahun 2000 mencapai 720.000 orang: 422.000 orang di negara maju dan 298.000 orang di negara yang sedang berkembang. Angka insiden tertinggi dapat di temukan pada beberapa daerah di Amerika Serikat (mencapai diatas 100/100.000 orang). Angka dibawah itu terlihat pada beberapa negara Eropa Barat (tertinggi di Swiss 73,5/100.000 orang) untuk Asia masih berkisar antara 10-20/100.000 orang (contoh pada daerah tertentu di Jepang 17,6/100.000 orang, Kuwait 17,2/100.000 orang dan China 9,5/100.000 orang). Insiden di negara maju Carsinoma (Ca) Mamae pada wanita dan pria masing-masing 87 dan 0,7/100.000 orang. Angka kematian kira-kira 27/100.000 orang. Menariknya, angka ini ternyata akan berubah bila populasi dari daerah dengan insiden rendah melakukan migrasi ke daerah yang insidennya lebih tinggi, suatu bukti adanya peran faktor lingkungan pada proses terjadinya kanker (Kusminarto, 2008).

Indonesia sendiri penyakit kanker merupakan penyebab kematian ke-5 dan mengalami peningkatan bermakna dimana kanker tertinggi di Indonesia adalah Carsinoma (Ca) Mamae diikuti kanker leher rahim (SIRS, 2007). Jumlah penderita kanker yang dirawat di rumah sakit di seluruh Indonesia bertambah dari tahun ketahun, demikian juga kematian bertambah karena naiknya jumlah penderita tersebut.
Data Depkes tahun 2009 memperkirakan 33.000 dari 177.000 kasus baru setiap tahun dirawat di rumah sakit di Indonesia. Tema peringatan Hari Kanker Sedunia tahun 2009 yang dicanangkan oleh Union International Against Cancer UICC adalah I Love My Healthy Active Childhood, dan Departemen Kesehatan adalah "Ayo aktif bergerak, bermain, dan makan makanan bergizi untuk cegah kanker". Insiden Carsinoma (Ca) Mamae di Indonesia masih belum diketahui secara pasti karena belum ada registrasi kanker berbasis populasi yang dilaksanakan tetapi berdasarkan data Globocan IARC tahun 2002, di dapatkan estimasi insiden Carsinoma (Ca) Mamae di Indonesia sebesar 26 per 100.000 perempuan (Evy, 2008).

Sementara berdasarkan data dari Badan Registrasi Kanker Ikatan Dokter Ahli Patologi Indonesia (IAPI), tahun 2009 di 13 rumah sakit di Indonesia Carsinoma (Ca) Mamae menduduki peringkat pertama dari seluruh kasus kanker sebesar 17,2 persen diikuti kanker leher rahim 12,2 persen.

Penyakit Carsinoma (Ca) Mamae di Indonesia menduduki urutan pertama diantaraantara penyakit lain, misalnya Propinsi Riau jumlah penderita Carsinoma (Ca) Mamae diprediksi mencapai 4000 orang per tahun. Di Yogyakarta dengan 342 kasus, Manado 234 kasus, Denpasar 230 kasus, Sulawesi Selatan 183 kasus, Palembang 174 kasus, Padang 140 kasus (Sudaryanto, 2009).

Berdasarkan data penderita Carsinoma (Ca) Mamae di RSUD Arifin Achmad periode 20052007 yang di dapatkan dari Medikal Record diperoleh data pada tahun 2005 penderita perempuan sebanyak 50 orang dan laki-laki 15 orang sehingga berjumlah 65 orang. Pada tahun 2006 terjadi peningkatan yaitu pada penderita perempuan sebanyak 228 orang dan laki-laki 17 orang sehingga berjumlah 245 orang. Pada tahun 2007 terjadi peningkatan yaitu pada penderita perempuan sebanyak 290 orang dan laki-laki 27 orang sehingga berjumlah 317 orang.

Dari data 15 penyakit terbesar di Bedah Umum (Cendrawasih I) RSUD Arifin Achmad Pekanbaru pada tahun 2008- 2009 diperoleh data bahwa penyakit Carsinoma (Ca ) Mamae berada 
pada urutan pertama dengan jumlah penderita pada tahun 2008 sebanyak 198 orang dan pada tahun 2009 sebanyak 213 orang.

\section{METODOLOGI PENELITIAN}

Dalam penelitian ini peneliti menggunakan jenispenelitian retrospektifdengan mengemukakan karakteristik penderita Carsinoma (Ca) Mamae berdasarkan usia, jenis kelamin, pendidikan dan pekerjaan yang dilakukan pada tanggal 14-28 Juli 2010 di RSUD Arifin Achmad Pekanbaru.

\section{Populasi dan Sampel}

Sampel penelitian ini adalah semua data pasien yang menjadi penderita Carsinoma (Ca) Mamae di RSUD Arifin Achmad Pekanbaru berdasarkancatatan Medikal Record Tahun (20082009). Sampel pada penelitian ini sebanyak 411 orang, dengan menggunakan metode purposive sampling yaitu teknik pengambilan sampel secara purposive didasarkan pada pertimbangan tertentu yang dibuat sendiri oleh peneliti, berdasarkan ciri atau sifat-sifat populasi yang sudah diketahui sebelumnya, dengan kriteria sampel semua penderita Carsinoma (Ca) Mamae dan memiliki catatan Rekam Medik yang di dalamnya mencakup variabel penelitian, yaitu: usia penderita Carsinoma (Ca) Mamae, jenis kelamin penderita Carsinoma ( $\mathrm{Ca}$ ) Mamae, pendidikan penderita Carsinoma (Ca) Mamae dan pekerjaan penderita Carsinoma $(\mathrm{Ca})$ Mamae

\section{Pengumpulan Data}

Dalam penelitian ini peneliti menggunakan data sekunder yang diperoleh dari Rekam Medik RSUD Arifin Achmad Pekanbaru tahun 2008-
2009, dan juga data melalui studi kepustakaan, bahan-bahan dari internet yang sesuai dengan bahasan masalah yang diteliti dengan menggunakan instrumen penelitian dalam bentuk lembar Check List.

\section{Pengolahan Data}

Menurut Hasan (2004),mengatakan bahwa dalam pengolahan data yang telah dikumpulkan diolah secara manual langkah-langkah pengolahan data editing, coding, tally, cleaning dan entry data.

\section{Analisa Data}

Dalam analisa peneliti menggunakan analisa univariate yaitu analisa yang digabungkan untuk melihat menggambarkan frekuensi dan persentase menurut Hasan (2004) dengan melihat persentase data yang terkumpul disajikan dalam bentuk tabel frekuensi dan tiap variabel dengan rumus:

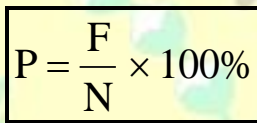

Keterangan:

$\mathrm{P}=$ Persentase

F=Frekuensi Penderita Carsinoma (Ca) Mamae berdasarkan usia, jenis kelamin, pendidikan dan pekerjaan

N=Jumlah kasus Penderita Carsinoma (Ca) Mamae

\section{HASIL DAN PEMBAHASAN Karakteristik Berdasarkan Usia}

Tabel 1. Distribusi frekuensi Usia Penderita Carsinoma (Ca) Mamae Tahun 2008-2009 di Ruang Cendrawasih I RSUD Arifin Achmad Pekanbaru Juli 2010

\begin{tabular}{|c|c|c|c|c|c|c|c|}
\hline \multirow{2}{*}{ No } & \multirow{2}{*}{ Usia (tahun) } & \multicolumn{2}{|c|}{$\mathbf{2 0 0 8}$} & \multicolumn{2}{c|}{$\mathbf{2 0 0 9}$} & \multicolumn{2}{c|}{ Total } \\
\cline { 2 - 8 } & & $\mathbf{F}$ & $\mathbf{\%}$ & $\mathbf{F}$ & $\mathbf{\%}$ & $\mathbf{F}$ & $\mathbf{\%}$ \\
\hline \hline 1 & 5-14 tahun & 1 & 0,50 & 1 & 0,47 & 2 & 0,49 \\
2 & $15-24$ tahun & 2 & 1,01 & 19 & 8,92 & 21 & 5,10 \\
3 & 25-44 tahun & 85 & 42,93 & 66 & 30,98 & 196 & 47,69 \\
4 & 45-64 tahun & 104 & 52,53 & 111 & 52,11 & 170 & 41,37 \\
5 & 65 tahun keatas & 6 & 3,03 & 16 & 7,52 & 22 & 5,35 \\
\hline & Jumlah & $\mathbf{1 9 8}$ & $\mathbf{1 0 0}$ & $\mathbf{2 1 3}$ & $\mathbf{1 0 0}$ & $\mathbf{4 1 1}$ & $\mathbf{1 0 0}$ \\
\hline
\end{tabular}




\section{Karakteristik Berdasarkan Jenis Kelamin}

Tabel 2. Distribusi Frekuensi Jenis Kelamin Penderita Carsinoma (Ca) Mamae Tahun 2008-2009 di Ruang Cendrawasih 1 RSUD Arifin Achmad Pekanbaru Juli 2010

\begin{tabular}{|c|c|c|c|c|c|c|c|}
\hline \multirow{2}{*}{ No } & \multirow[b]{2}{*}{ Jenis Kelamin } & \multicolumn{2}{|c|}{2008} & \multicolumn{2}{|c|}{2009} & \multicolumn{2}{|c|}{ Total } \\
\hline & & $\mathbf{F}$ & $\%$ & $\mathbf{F}$ & $\%$ & $\mathbf{F}$ & $\%$ \\
\hline 1 & Laki-Laki & 4 & 2,02 & 1 & 0,47 & 5 & 1,21 \\
\hline 2 & Perempuan & 194 & 97,98 & 212 & 99,53 & 406 & 98,79 \\
\hline & Jumlah & 198 & 100 & 213 & 100 & 411 & 100 \\
\hline
\end{tabular}

\section{Karakteristik Berdasarkan Tingkat Pendidikan}

Tabel 3. Distribusi Frekuensi Tingkat Pendidikan Penderita Carsinoma (Ca) Mamae Tahun 2008-2009 di Ruang Cendrawasih 1RSUD Arifin Achmad Pekanbaru Juli 2010

\begin{tabular}{|c|l|c|c|c|c|c|c|}
\hline \multirow{2}{*}{ No } & \multicolumn{2}{|c|}{ Tingkat Pendidikan } & \multicolumn{2}{|c|}{$\mathbf{2 0 0 8}$} & \multicolumn{2}{c|}{ 2009 } & \multicolumn{2}{c|}{ Total } \\
\cline { 3 - 8 } & F & \% & F & \% & F & \% \\
\hline \hline 1 & Rendah (SD, SMP) & 170 & 85,86 & 188 & 88,27 & 358 & 87,11 \\
2 & Menengah (SMA) & 24 & 12,12 & 22 & 10,33 & 46 & 11,19 \\
3 & Perguruan Tinggi (DIII, SI, SII) & 4 & 2,02 & 3 & 1,40 & 7 & 1,70 \\
\hline & Jumlah & $\mathbf{1 9 8}$ & $\mathbf{1 0 0}$ & $\mathbf{2 1 3}$ & $\mathbf{1 0 0}$ & $\mathbf{4 1 1}$ & $\mathbf{1 0 0}$ \\
\hline
\end{tabular}

\section{Karakteristik Berdasarkan Jenis Pekerjaan}

Tabel 4. Distribusi Frekuensi jenis pekerjaan Penderita Carsinoma (Ca) Mamae Tahun 2008-2009 di Ruang Cendrawasih 1RSUD Arifin Achmad Pekanbaru Juli 2010

\begin{tabular}{|c|c|c|c|c|c|c|c|}
\hline \multirow{2}{*}{ No } & \multirow{2}{*}{ Jenis Pekerjaan } & \multicolumn{2}{|c|}{2008} & \multicolumn{2}{|c|}{2009} & \multicolumn{2}{|c|}{ Total } \\
\hline & & $\mathrm{F}$ & $\%$ & $\mathrm{~F}$ & $\%$ & $\mathrm{~F}$ & $\%$ \\
\hline 1 & IIRT & 183 & 92,42 & 193 & 90,61 & 376 & 91,48 \\
\hline 2 & Swasta & 11 & 5,56 & 14 & 6,58 & 25 & 6.08 \\
\hline 3 & PNS & 4 & 2,02 & 6 & 2,81 & $\begin{array}{l}25 \\
10\end{array}$ & $\begin{array}{l}6,08 \\
2,44\end{array}$ \\
\hline & Jumlah & 198 & 100 & 213 & 100 & 411 & 100 \\
\hline
\end{tabular}

Berdasarkan Hasil penelitian yang telah dilakukan peneliti tentang"Gambaran Karakteristik Penderita Carsinoma (Ca) Mamae tahun 2008-2009 di Ruang Cendrawasih I RSUD Arfin Achmad Pekanbaru, yang dilakukan pada tanggal 14-28 Juli 2010 adalah sebagai berikut:

\section{Karakteristik Usia Penderita Carsinoma (Ca) Mamae}

Karakteristik penderita Carsinoma (Ca) Mamae pada penelitian ini adalah mayoritas berada pada usia 45-64 tahun. Pada tahun 2008 sebanyak 104 orang $(52,53 \%)$, dan pada tahun 2009 sebanyak 111 orang $(52,11 \%)$. Disini peneliti menemukan terjadi peningkatan dari tahun 2008 -2009, Carcinoma (Ca) mamae merupakan penyakit yang berhubungan dengan penuaan. Resikonya meningkat tajam pada usia 45-65 Tahun (Price, 2006). Hal ini disebabkan karena terjadinya ketidakseimbangan antara estrogen dan progesteron. Walaupun setelah umur 45 tahun produksi estrogen ovarium berkurang karena ovarium yang semakin mengecil, tetapi jaringan Perifer seperti lemak hati dan ginjal masih dapat menghasilkan estrogen. Sedangkan produksi progesteron semakin berkurang seiring semakin tuanya umur ovarium (Heffner \& Schust, 2006).

Menurut hasil penelitian Nurmaya (2007), dengan judul "Karakteristik Penderita Kanker Payudara di Rumah Sakit St. Elisabeth Medan Tahun 2003-2006", diperoleh data dan kesimpulan bahwa pada umumnya kasus penderita kanker payudara berada pada usia 45-65 tahun $(74,8 \%)$.

Hal ini juga didukung oleh hasil penelitian Kusmayanti (2005) dengan judul "Gambaran Karakteistik Pasien Kanker Payudara Di Rumah 
Sakit Kanker Dharmais tahun 2000-2004", menunjukkan usia 45-65 tahun $(67,3 \%)$ menderita kanker payudara 10 kali bila di bandingkan wanita yang berusia 30-40 tahun.

Menurut Dadang (2002) dalam Hendra (2008), mengemukakan bahwa faktor prognostik karakteristik yang berpengaruh terhadap ketahanan hidup penderita kanker payudara famial adalah usia dan derajat diferesiensi histologis. usia paling berpengaruh terhadap ketahanan tubuh.

Hal ini didukung oleh pendapat Suhardjho (2003), dalam penelitiannya yang berjudul "Faktor Resiko Penderita Kanker Payudara" yang dilakukan terhadap 89 responden bahwa Usia yang Menderita Kanker Payudara Mayoritas usia 45-65 tahun sejumlah 35 responden $(43,8 \%)$.

Menurut asumsi peneliti usia juga dapat mempengaruhi tingkat kesehatan seseorang. Oleh sebab itu, semakin bertambahnya usia seseorang, daya tahan tubuh seseorang semakin menurun.

Dapat disimpulkan bahwa bertambahnya usia seseorang dapat berpengaruh pada derajat kesehatan dan daya tubuh seseorang akan mulai menurun dengan bertambahnya usia karena timbulnya kerentanan kondisi fisik, baik anatomis maupun fungsionalnya.

\section{Karakteristik Jenis Kelamin}

Karakteristik penderita Carsinoma (Ca) Mamae pada penelitia ini mayoritas pada perempuan, pada tahun 2008 sebanyak 194 orang (97,98\%), dan pada tahun 2009 sebanyak 212 orang $(99,53 \%)$. Peneliti menemukan bahwa perempuan lebih mendominasi dari laki-laki tiap tahunnya. Laki-laki dan perempuan semua mempunyai jaringan payudara. Berbagai macam hormon pada perempuan menstimulasi jaringan pada payudara sedemikian rupa sehingga membentuk payudara penuh. Sedangkan pada tubuh laki-laki secara normal tidak ada stimulasi hormon pada payudara. Akibatnya jaringan payudaranya tetap kecil dan rata. Ada juga, sering kita lihat laki-laki dengan ukuran payudara besar. Biasanya itu hanya karena gemuk. Tapi kadang ada beberapa pria jaringan kelenjar payudaranya tumbuh, itu disebabkan karena mereka menggunakan beberapa obat, pecandu alkohol, pengguna marijuana (ganja) atau mempunyai tingkat hormon yang tidak normal (Hawari,2004).

Menurut hasil penelitian Andi (2007) dengan judul "Penderita Kanker Payudara di Rumah Sakit Kanker Dharmais Jakarta tahun 2005-2007". Yang berjenis kelamin perempuan Dari tahun 2005-2007 mencapai (94,45\%). Sedangkan pada laki-laki pada tahun yang sama hanya $(5,55 \%)$.

Hal ini didukung oleh penelitian Tisrina (2003) dengan judul "Deskripsi Data Rekam Medis Penyakit Kanker Payudara Rumah Sakit Kanker Dharmais pada Bulan Oktober Tahun 2000 sampai pada bulan Maret tahun 2003", yang menyatakan bahwa tingkat penderita kanker payudara berdasarkan jenis kelamin, terdiri dari 753 perempuan dan 10 laki-laki.

Hal ini diperkuat oleh pendapat Partoharjo (2007), yang menyatakan bahwa laki-laki dapat menderita kanker payudara, hal ini berkaitan dengan faktor hormonal, adanya perubahan metabolisme hormonal yaitu esterogen. Dimana didapatkan penurunan estrone dan peningkatan estriol dalam darah.

Menurut hasil penelitian Achmad (2002) dengan judul "Karakteristik Penderita Kanker Payudara yang Dirawat Inap di Rumah Sakit St. Elisabeth Medan Tahun 2000-2002" di peroleh data dan kesimpulan bahwa dari 215 kasus yang di temukan mayoritas berjenis kelamin perempuan sebanyak $(89,7 \%)$.

\section{Karakteristik Pendidikan}

Karakteristik penderita Carsinoma (Ca) Mamae yaitu mayoritas pendidikan rendah. Pada tahun 2008 sebanyak 170 orang $(85,86 \%)$, dan pada tahun sebanyak 188 orang $(88,27 \%)$. Dapat dilihat terjadi peningkatan dari tahun 2008-2009 . Menurut Hikmat (2007) Pendidikan diperkirakan ada kaitannya dengan pola pikir seseorang dalam memahami dunia kesehatan, karena Seseorang yang berpendidikan tinggi cenderung lebih memperhatikan kesehatan dirinya.

Menurut penelitian Iskandar (2006) dengan judul "Gambaran Penderita Kanker Payudara di Kota Bandung Tahun 2005", didapatkan data bahwa penderita kanker payudara terus meningkat, yang lebih mengejutkan lagi, dari 1,1 juta penderita kanker payudara, 65 persen 
diantaranya adalah berpendidikan rendah (SD dan SMP).

Menurut Alkaff (2004), jumlah penderita kanker payudara di Indonesia yang terbanyak berasal dari kalangan berpendidikan rendah, 3,2 juta jiwa $(78,75 \%)$ dari penduduk Indonesia yang berjumlah 260 juta.

Ini sesuai dengan penelitian Prastika (2007), yang berjudul "Gambaran Karaketristik Kanker Payudara di Rumah Sakit Dharmis tahun 20002006" angka yang paling banyak menjadi penderita kanker payudara adalah yang berpendidikan rendah. jumlah penderita kanker payudara mencapai angka 1.225 kasus, sementara yang berpendidikan menengah mencapai 853 kasus.

Hasil penelitian ini sesuai dengan pendapat Notoatmodjo (2002), Pendidikan merupakan cara yang utama untuk memperoleh pengetahuan. Seseorang yang berpendidikan tinggi cenderung lebih memperhatikan kesehatan dirinya.

\section{Karakteristik Pekerjaan}

Karakteristik penderita Carsinoma (Ca) Mamae berdasarkan jenis pekerjaan yaitu mayoritas Ibu Rumah Tangga (IRT). pada tahun 2008 sebanyak 183 orang $(92,42 \%)$, dan pada tahun 2009 sebanyak 193 orang $(90,61 \%)$. Menurut harison (2002), hal ini disebabkan oleh faktor hormonal, faktor genetik dan faktor lingkungan, yaitu:

\section{Faktor Hormonal}

Menopause yang lambat dan kehamilan pertama yang muncul pada usia lanjut berkaitan dengan peningkatan insiden Carsinoma (Ca) Mamae, Selain itu, pemberian hormon, misalnya terapi pengganti hormon estrogen untuk gejala pasca menopause atau kontrasepsi untuk mengatur kelahiran diduga juga akan meningkatkan pertumbuhan Carsinoma (Ca) Mamae.

\section{Faktor Genetik}

Bukti yang terus bermunculan menunjukkan bahwa perubahan genetik berkaitan dengan terjadinya Carsinoma (Ca) Mamae, namun apa yang menyebabkan perubahan genetik tersebut masih belum diketahui. Perubahan genetik ini termasuk perubahan atau mutasi dalam gen normal dan pengaruh protein, baik yang menekan atau meningkatkan perkembangan Carsinoma (Ca) Mamae. Hampir 5 persen dari semua pasien Carsinoma (Ca) Mamae mewarisi kelainan genetik spesifik yang berperan dalam pembentukan Carsinoma (Ca) Mamae mereka. Wanita yang ibu atau saudara perempuannya mengidap Carsinoma (Ca) Mamae memiliki risiko lebih tinggi untuk terserang penyakit yang sama, lebih-lebih bila anggota keluarga tadi mengalaminya pada kedua belah buah dadanya.

\section{Faktor Lingkungan}

Faktor lingkungan atau faktor eksogen yang dapat meningkatkan insiden Carsinoma (Ca) Mamae adalah pengaruh radiasi sinar $\mathrm{X}$, virus dan zat kimia. Selain itu, seringnya para wanita mengkonsumsi makanan berlemak tinggi dan kurang berolahraga juga dapat meningkatkan risiko Carsinoma (Ca) Mamae

Hal ini didukung oleh penelitian Tisrina (2003) yang menyatakan bahwa tingkat penderita kanker payudara berdasarkan pekerjaan dari 763 kasus $(57,8 \%)$ mayoritas ibu rumah tangga (IRT).

Menurut hasil penelitian Nurmaya (2007), diperoleh data dan kesimpulan bahwa pada umumnya kasus penderita kanker payudara berdasarkan pekerjaan adalah ibu rumah tangga (IRT) sebanyak 103 orang $(55,3 \%)$.

Hal serupa juga diungkapkan oleh Hendra (2006) dalam penelitianya yang berjudul "Gambaran Karakteristik Kanker Payudara yang Berhubungan Dengan Pekerjaan di Kota Semarang", bahwa jumlah/penderita kanker payudara dikalangan ibu rumah tangga naik tajam pada tahun 2006 sekitar 13.914 orang, padahal tahun 2005 hanya 8.143 ibu rumah tangga, lima tahun sebelumnya yaitu pada tahun 2001 penderita kanker payudara dari kalangan ibu rumah tangga hanya 1.228 orang.

Sedangkan menurut Suniar (2008) pada akhir November 2006 penderita kanker payudara dikalangan ibu rumah tangga kembali meningkat tajam sekitar lima kali lipat dari tahun 2001, yaitu $(20,24 \%)$.

Hal ini diperkuat oleh pendapat Veronika (2004), menemukan adanya masalah kesehatan yang tinggi pada masyarakat miskin terutama 
pada penderita Carsinoma (Ca) Mamae. Terlebih ketika hal ini terjadi pada masyarakat miskin ekstrem yang tidak sama sekali memiliki akses terhadap fasilitas kesehatan.

\section{KESIMPULAN DAN SARAN}

Berdasarkan hasil penelitian yang telah dilaksanakan peneliti pada tanggal 14-28 Juli 2010 yang berjudul "Gambaran karakteristik penderita carsinoma (Ca) Mamae tahun 20082009 di Ruang Cendrawasih I RSUD Arifin Achmad Pekanbaru, yaitu dengan menggunakan lembar Check List yang berisikan karakteristik penderita Carsinoma (Ca) Mamae tahun 20082009 yang tercatat di Rekam Medik RSUD Arifin Achmad Pekanbaru yang dapat disimpulkan sebagai berikut:

a. Karakteristik penderita Carsinoma (Ca) Mamae tahun 2008-2009 di Ruang Cendrawasih I RSUD Arifin Achmad Pekanbaru, tentang karakteristik penderita Carsinoma (Ca) Mamae berdasarkan usia yang terbanyak tahun 2008-2009 adalah mayoritas berusia 45-64 tahun. Pada tahun 2008 usia 45-64 tahun sebanyak 104 orang (52,53\%) dan pada tahun 2009 usia 45-64 tahun sebanyak 111 orang $(52,11 \%)$.

b. Karakteristik penderita Carsinoma (Ca) Mamae tahun 2008-2009 di Ruang Cendrawasih I RSUD Arifin Achmad Pekanbaru, tentang karakteristik penderita Carsinoma (Ca) Mamae berdasarkan jenis kelamin Mayoritas perempuan. Pada tahun 2008 sebanyak 194 orang $(97,98 \%)$ dan pada tahun 2009 sebanyak 212 orang $(99,53 \%)$.

c. Karakteristik penderita Carsinoma (Ca) Mamae tahun 2008-2009 di Ruang Cendrawasih I RSUD Arifin Achmad Pekanbaru, tentang karakteristik berdasarkan tingkat pendidikan mayoritas berpendidikan rendah. Pada tahun 2008 sebanyak 170 orang $(85,86 \%)$ dan pada tahun 2009 sebanyak 188 orang $(88,27 \%)$.

d. Karakteristik penderita Carsinoma (Ca) Mamae tahun 2008-2009 di Ruang Cendrawasih I RSUD Arifin Achmad Pekanbaru, tentang karakteristik berdasarkan pekerjaan mayoritas Ibu Rumah Tangga
(IRT). Pada tahun 2008 sebanyak 183 orang $(92,42 \%)$ dan pada tahun 2009 sebanyak 193 orang $(90,61 \%)$.

\section{DAFTAR PUSTAKA}

Achmad. (2002). Karakteristik Penderita Kanker Payudara yang Dirawat Inap di Rumah Sakit St. Elisabeth Medan Tahun 20002002. Diperoleh tanggal 2 Agustus 2010 dari http://www.depsos.go.id.

Andi. (2007). Penderita Kanker Payudara di Rumah Sakit Kanker Dharmais Jakarta tahun 2005-2007, Diperoleh tanggal 2 Agustus 2010 dari http://www.depsos.go.id. Alkaff. (2004). Penderita Kanker Payudara Di Indonesia. Diperoleh pada tanggal 2 Agustus 2010 dari http:// www.wordpress.com.

Chrisna. (2008). Kanker Payudara Kian Mengancam. Diperoleh tanggal 12 Oktober 2009 dari http://chrisna.blogdetik.com.

Evy. (2008). Deteksi Kanker Leher Rahim dan Payudara Sedini Mungkin. Diperoleh tanggal 12 Oktober 2009 dari http://www.kompas.com.

Hasan. (2004). Analisa Data Penelitian Statistik. Jakarta: Bumi aksara.

Hawari, D. (2004). Kanker Payudara Dimensi Psikoreligi. Jakarta: Balai Pustaka FKUI.

Heffner \& Schust. (2006). Sistem Reproduksi. Jakarta: Erlangga.

Hendra. (2006), Gambaran Karakteristik Kanker Payudara yang Berhubungan Dengan Pekerjaan di Kota Semarang. Diperoleh pada tanggal 2 Agustus 2010 dari http://repositoriguna darma.ac.id.

Hikmat, M. Mahi. (2007). Awas Bahaya kanker. Bandung: Grafitri Budi Utama.

Kusmayanti. (2005). Gambaran Karakteistik Pasien Kanker Payudara Di Rumah Sakit Kanker Dharmais tahun 2000-2004, Diperoleh pada tanggal 2 Agustus 2010 dari http:// www.wordpress.com.

Kusminarto. (2008). Deteksi Sangat Dini Kanker Payudara, Jawaban untuk Menghindar. Diperoleh tanggal 12 Oktober 2009 dari http://www.depkes.go.id. 
Mangan, Y. (2004). Cara Bijak Menaklukkan Kanker. Jakarta: Agro Media Pustaka.

Nurmaya. (2007). Karakteritik Penderita Kanker Payudara di Rumah Sakit St. Elizabet Medan tahun 2003-2006. Diperoleh pada tanggal 2 Agustus dari http:// www.wordpress.com.

Notoatmodjo, S. (2002). Metodologi Penelitian Kesehatan. Jakarta: Rineka Cipta.

Partodtharjo. (2007). Etilogi dan faktor kanker Payudara..Diperoleh pada tanggal 2Agustus dari http://www.wordpress.com.

Prastika. (2007). Gambaran Karaketristik Kanker Payudara di Rumah Sakit Dharmis tahun 2000-2006. Diperoleh 2 Agustus 2008 dari http://www.bangrusli.net.

Price, S. (2006). Patofisiologi. Jakarta: EGC. Suhardjo. (2003). Faktor Resiko Penderita Kanker Payudara. Diperoleh pada tanggal 2
Agustus 2009 dari www. Mediaindo. Co. Id.

Suniar. (2008). Penderita kanker payudara di kalangan ibu rumah tangga. Diperoleh tanggal 2 Agustus 2010 dari http://www.google.com.

Tisrina. (2003). Deskripsi Data Rekam Medis Penyakit Kanker Payudara Rumah Sakit Kanker Dharmais pada Bulan Oktober Tahun 2000 sanmpai pada bulan Maret tahun 2003. Diperoleh tanggal 2 Agustus 2010 dari http://www.google.com.

Veronica. (2008). Kemiskinan Mengancam Kesehatan. Diperoleh tanggal 25 Mei 2010 dari http://www.mediaindonesi.com.

Zaluchu, F. (2005). Metodologi Penelitian Kesehatan. Bandung: Cipta pustaka Media. 